\title{
Banking Crisis Solutions Old and New
}

\author{
Alistair Milne and Geoffrey Wood
}

\begin{abstract}
In 2007 Britain experienced its first run on a bank of any macroeconomic significance since 1866. This was not dealt with by the method that had maintained banking stability for so long: letting the bank fail but supplying abundant liquidity to the markets to prevent contagion. In this paper the authors examine why that traditional solution was not used and propose changes to Britain's deposit insurance system, to its bank insolvency regime, and in arrangements to allow customers access to banking services should their bank be closed-so that the traditional approach can once more be used to mitigate moral hazard. (JEL E58, G21, G28)
\end{abstract}

Federal Reserve Bank of St. Louis Review, September/October 2008, 90(5), pp. 517-30.

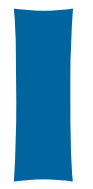

$\mathrm{n}$ the autumn of 2007 Britain experienced its first bank run of any significance since the reign of Queen Victoria. ${ }^{1}$ The run was on a bank called Northern Rock. This was extraordinary; by the early 1870s, the Bank of England had developed techniques to prevent such events. Further, it was the announcement of support for the troubled institution that triggered the retail run. (We emphasize "retail" because the bank had already been experiencing great difficulty in obtaining wholesale funding.) That run was halted only when the Chancellor of the Exchequer (as Britain's minister of finance is known), then Alistair Darling, announced that he would commit taxpayers' funds to guarantee every deposit at Northern Rock.

This paper has two aims: first, to address the question of why the United Kingdom's traditional techniques for maintenance of banking stability failed-if they did fail—on this occasion; and

1 There were runs on some "fringe banks" in the secondary banking crisis of 1973-74. See Reid (1976) for details. second, to consider how these techniques may need to be changed or supplemented to prevent any similar problems in the United Kingdom.

\section{CHRONOLOGY OF EVENTS}

Northern Rock was created by the merger of two "building societies," the Northern Counties and the Rock, on July 1, 1965. Building societies were mutual organizations, owned by their depositors and their borrowers. Their deposits came primarily from retail customers, and their major (essentially sole) lending activity was to individuals to buy residences. In the 1990s these organizations were allowed to demutualize and "convert" (in the terminology of the time) to banks. Most large societies converted, and Northern Rock was among them. It demutualized on October 1, 1997.

Many of these demutualized societies were taken over by or merged with existing banks. Northern Rock remained independent. Two other features of its post-demutualization behavior were

Alistair Milne is a reader in economics and Geoffrey Wood is a professor of economics at Cass Business School, London, England. The authors thank Josephine Fogden for research assistance and Rae Balbach, Anna Schwartz, and the participants at a conference held by the Federal Reserve Bank of St. Louis on March 3, 2008, in honor of Ted Balbach for their comments.

(C) 2008, The Federal Reserve Bank of St. Louis. The views expressed in this article are those of the author(s) and do not necessarily reflect the views of the Federal Reserve System, the Board of Governors, or the regional Federal Reserve Banks. Articles may be reprinted, reproduced, published, distributed, displayed, and transmitted in their entirety if copyright notice, author name(s), and full citation are included. Abstracts, synopses, and other derivative works may be made only with prior written permission of the Federal Reserve Bank of St. Louis. 
distinctive. First, it grew very rapidly. At the end of 1997, its assets (on a consolidated basis) stood at $£ 15.8$ billion. By the end of 2006, its assets had reached $£ 101.0$ billion. Even so, at the end of the second quarter of 2007, its loans were only 8 percent (by value) of the stock of mortgage debt in the United Kingdom and therefore only about 5 percent of total bank lending, and its deposits about 2 percent of sterling bank deposits. It was certainly not an enormous institution. The second feature relates to its activity. On the asset side of the balance sheet it remained close to the traditional building society model: It stayed concentrated on mortgage lending to individuals wishing to buy their own homes. There were, however, dramatic changes in the structure of its liabilities. It adopted an "originate to distribute" model of funding (the originated mortgages would be sold in wholesale markets).

The resulting dependence on wholesale markets for the large majority of its funding was what most distinguished Northern Rock from other U.K. banks. Retail deposits (and other classes of retail funds) did grow, but not nearly as rapidly as wholesale funds, so retail funds fell as a proportion of total liabilities and equity, from 62.7 percent at year-end 1997 to 22.4 percent at yearend 2006. But on August 9, 2007, there was a sharp dislocation in the market for Northern Rock's funding, with the start of a major repricing of credit risk in global financial markets.

\section{INSTITUTIONAL CONTEXT}

This section briefly describes the institutional setting within which the problems were addressed. The structure of regulation is considered first and is followed by a discussion of the way in which the Bank of England conducted its money market operations.

The Bank of England had been given operational independence to set interest rates to achieve an inflation target determined by the Chancellor of the Exchequer by the Bank of England Act 1998. As part of that change, it lost responsibility for bank supervision to the Financial Services Authority (FSA), a new agency created at the same time and charged with the task of supervising the entire financial sector. Notably, although the FSA had the duty of supervising individual banks, the Bank of England retained responsibility for stability of the financial system as a whole. The Treasury also shared responsibility for stability and supervision: If any risks had to be taken with taxpayers' money, the Treasury had the money and the right to use it. The three institutions together are known as the Tripartite Authorities.

Another factor was important at that time. The way in which money market operations were conducted also had changed recently. A new operating procedure had been devised because of concern over the volatility of short-term sterling rates. Banks were allowed to specify for each reserve maintenance period the amount of cash they wanted from the Bank of England at the Bank's policy rate. If they found they needed less than the specified amount, they could redeposit the cash at the Bank at a rate below the policy rate; if they needed more, they could get it at a rate above the policy rate. The new regulatory system and the new money market procedures both seemed to have worked smoothly before the Northern Rock episode, but this was their first test under stress.

\section{THE MARKET FREEZE}

Soon after interbank and other financial markets froze on August 9, it became clear that Northern Rock would face severe problems if the markets remained frozen for long. The thenchairman and the then-chief executive of Northern Rock first discussed these problems with each other on Friday, August $10 .^{2}$ That same day the FSA contacted the businesses that it believed

\footnotetext{
2 See question 391 (Q 391) in the following source: House of Commons Treasury Committee (2008b): The run on the Rock, Fifth Report of Session 2007-08, volume II. "Q 391" here refers to question 391 in this publication. In this and subsequent footnotes, referenced questions follow the same format. Multiple questions are referenced by "Qq." Access www.parliament.the-stationeryoffice.co.uk/pa/cm200708/cmselect/cmtreasy/56/56ii.pdf for the complete text of questions (and answers) cited herein. For additional documentation, see House of Commons Treasury Committee (2008a).
} 
might be at risk from the freezing of financial markets. One of these was Northern Rock. ${ }^{3}$ Northern Rock replied to the FSA on the next working day, Monday, August 13. Thereafter, the FSA and Northern Rock were in twice-daily telephone contact. ${ }^{4}$

Between August 10 and mid-September, Northern Rock and the Tripartite Authorities pursued a threefold strategy to extricate Northern Rock from its difficulties. The three options (discussed in detail in the following text) were as follows:

- Northern Rock could resolve its liquidity problems through its own actions in shortterm money markets and by securitizing its debt ${ }^{5}$;

- Northern Rock could obtain the "safe haven" of a takeover by a major retail bank ${ }^{6}$; and

- Northern Rock could receive a support facility from the Bank of England guaranteed by the government.

\section{THE FIGHT TO SAVE NORTHERN ROCK}

\section{Did the Bank of England Provide Sufficient Liquidity Assistance?}

Northern Rock's resolution of its liquidity problems through its own actions would have required that short-term funds be available in money markets at rates in line with adjustable mortgage rates and other short-term interest rates (i.e., in an environment in which there was no general shortage of bank liquidity). Some commentators have suggested that failure by the Bank to provide sufficient assistance to the money markets forced Northern Rock to turn to the Bank for a support facility. In August 2007, the Bank of England was approached by banks arguing that

${ }^{3} \mathrm{Q} 1523$.

${ }^{4}$ Q 568.

${ }^{5}$ Qq 108, 200, 611.

${ }^{6} \mathrm{Q} 613$. the Bank should provide additional liquidity at the regular (no penalty) rate. The Bank refused such assistance.

The commercial banks raised their reserve requirements by 6 percent in the maintenance period starting September 6, 2007. On September 5-before the start of the September 6 maintenance period-the Bank of England announced that if the secured overnight rate had not fallen from its higher-than-usual level above Bank rate, the Bank would have been prepared to offer additional reserves, amounting to 25 percent of the requested reserves target, before the end of the "maintenance period."7 (This period is approximately one month; it runs from one monthly meeting of the Bank's Monetary Policy Committee to the next.) On September 13, this criterion was met and additional reserves were provided. An additional fine-tuning operation occurred on September 18 after the run on Northern Rock; the Bank again offered $£ 4.4$ billion, or 25 percent of the reserves target.

Would provision of this extra liquidity at the time the banks first requested it have saved Northern Rock? It seems very unlikely that any such general lending operation would have been of a sufficient scale to ensure that Northern Rock received the liquidity it required. Banks would have wanted to ensure that they were themselves secure; and even when thus satisfied, there would have been reluctance to lend any extra funds to a bank about which many by then had doubts. It seems likely that only lending by the Bank specifically targeted on Northern Rock would have helped, and that approach was not initially considered.

\section{Would a Safe Haven Be Found?}

On August 16, Northern Rock began its pursuit of a "safe haven," acting "behind the scenes" and with its advisers to seek an offer for the company. ${ }^{8}$ Two institutions showed interest in acquiring Northern Rock. One showed only "a slight expression of interest...that never came to anything."9

\footnotetext{
${ }^{7} \mathrm{Q} 613$.

8 Qq 571, 732.

9 Qq 749, 754.
} 
The second institution, a major High Street retail bank, ${ }^{10}$ showed "more specific interest" for a period of two or three days, but no firm offer was made. ${ }^{11}$ Northern Rock ceased its pursuit of a safe haven on Monday, September $10 .^{12}$

This option failed for two main reasons. The bidder (the second institution) wanted liquidity support in the form of a loan; there was, in the words of the Governor of the Bank of England, a request to "borrow about $£ 30$ billion without a penalty rate for two years." 13 Both the Chancellor of the Exchequer and the Governor indicated that they were reluctant to let the Bank act as a commercial lender to a going concern. ${ }^{14}$

The Chancellor of the Exchequer and the Governor also agreed that a legal barrier prevented the provision of financial support. If such lending were to be made available to one High Street bank, it would have been necessary to have offered a matching facility to other potential bidders. ${ }^{15} \mathrm{In}$ addition, the Governor emphasized the legal difficulties faced in current circumstances in accomplishing a rapid takeover of a bank that is a quoted company (a company whose shares are traded on the London stock exchange): “....any change of ownership of a quoted company-and Northern Rock is a quoted company-cannot be managed except through a long and prolonged timetable set out in the Takeover Code."16

Before the run the FSA, the Governor of the Bank of England, and the Chancellor of the Exchequer all favored a solution to Northern Rock's problems through a private sector takeover. The Chancellor of the Exchequer stated that a merger "would have been by far the best option."17 But a rapid takeover was not possible, and there was no time for one to proceed at the normal pace.

\footnotetext{
${ }^{10} \mathrm{Q} 588$.

${ }^{11} \mathrm{Q} 754$.

${ }^{12}$ Qq 571, 577.

${ }^{13} \mathrm{Q} 1665$.

${ }^{14}$ Qq 789, 1665.

${ }^{15}$ Qq 1665, 789.

${ }^{16} \mathrm{Q} 5$.

${ }^{17}$ Qq 257, 3, 790.
}

\section{Why a Bank of England Support Operation?}

By Monday, September 10, it was evident that a Bank of England support operation for Northern Rock would be necessary for Northern Rock to avoid defaulting on its short-term borrowing. By the following day, it was apparent that that operation would need to be publicly announced. ${ }^{18}$ Stock exchange rules required this announcement-it was an undeniably "material event"and the announcement was made at 7 a.m. on Friday, September 14:

The Chancellor of the Exchequer has today authorised the Bank of England to provide a liquidity support facility to Northern Rock against appropriate collateral and at an interest rate premium. This liquidity facility will be available to help Northern Rock to fund its operations during the current period of turbulence in financial markets while Northern Rock works to secure an orderly resolution to its current liquidity problems...The FSA judges that Northern Rock is solvent, exceeds its regulatory capital requirement and has a good quality loan book. ${ }^{19}$

But before the provision of emergency liquidity assistance by the Bank of England to Northern Rock could be announced formally, the outlines of the operation were reported by the BBC News the previous evening. This was followed by a retail run on Northern Rock. Some have blamed the BBC announcements for this run, but doing so neglects the fact that announcements of official support for banks often trigger runs. Regardless of the cause of the run, the speed and extent of withdrawals meant that the Bank of England's emergency facility, which had been envisaged as a "backstop" that would allow Northern Rock time to raise lower-cost short-term funds in wholesale markets, had to be called upon almost immediately. $^{20}$

The momentum of the run on Northern Rock retail deposits was due to two factors. First, depos-

\footnotetext{
${ }^{18} \mathrm{Q} 1620$.

19 Bank of England (2007).

${ }^{20} \mathrm{Q} 529$.
} 
itors became aware that, if the run continued, Northern Rock would eventually cease to be a going concern. ${ }^{21}$ Second, public awareness that deposits above $£ 2,000$ were not guaranteed in full increased; this fact was something of which many depositors may previously have been unaware. ${ }^{22}$ The Governor of the Bank of England said that, in these circumstances, the only way to halt the run was to provide a government guarantee of deposits in Northern Rock. ${ }^{23}$ The Chancellor of the Exchequer "became convinced" on Sunday, September 16, that action along these lines was necessary. ${ }^{24}$ The announcement of a government guarantee late on Monday, September 17, had the desired effect. The run was halted. ${ }^{25}$

\section{A Lender-of-Last-Resort Operation?}

The decision to provide support to Northern Rock has been described as a "lender of last resort" operation, but it was certainly not what we would term a classic lender-of-last-resort operation. That procedure evolved in Britain in the nineteenth century to prevent a general loss of confidence in the safety of bank deposits (i.e., to prevent a general run from banks to cash).

The concept of a lender of last resort was described in its essentials, and named, by Francis Baring in 1797 in his comment on financial consequences of the 1793 declaration of war between France and Britain ${ }^{26}$ :

That dreadful calamity is usually preceded by some indication which enables the commercial and monied men to make preparation. On this occasion the short notice rendered the least degree of general preparation impossible. The foreign market was either shut, or rendered more difficult of access to the merchant. Of course he would not purchase from the manu-

\footnotetext{
${ }^{21} \mathrm{Q} 57$.

${ }^{22} \mathrm{Q} 677$.

${ }^{23}$ Qq 46, 57.

${ }^{24} \mathrm{Q} 1760$.

${ }^{25} \mathrm{Q} 1760$.

${ }^{26}$ A detailed description of the evolution of this classic lender of last resort can be found in Wood (2000).
}

facturers;...the manufacturers in their distress applied to the Bankers in the country for relief; but as the want of money became general, and that want increased gradually by a general alarm, the country Banks required the payment of old debts...In this predicament the country at large could have no other resource but London; and after having exhausted the bankers, that resource finally terminated in the Bank of England. In such cases the Bank are not an intermediary body, or power; there is no resource on their refusal, for they are the dernier resort. ${ }^{27}$

Shortly after Francis Baring's 1797 use of the term “dernier resort," Henry Thornton (1802) provided a statement of what it was, why it was necessary, and how it should operate. Quite remarkably, this statement was essentially a complete description of the lender-of-last-resort role as it was performed until the beginning of this century. Thornton's statement was made in a particular institutional context, and for clarity's sake this context is further detailed here. ${ }^{28}$

All banks in England (except the Bank of England) were constrained to be partnerships of six or fewer members. The joint stock form was not generally allowed until 1826 and limited liability not until 1858. Failures were common despite the risk aversion on the part of bankers that unlimited liability surely brought. It is here that the Bank of England comes into play:

If any bank fails, a general run upon the neighbouring banks is apt to take place, which if not checked in the beginning by a pouring into the circulation of a very large quantity of gold, leads to very extensive mischief.

(Thornton, 1802, p. 182)

\footnotetext{
${ }^{27}$ This quotation is from the Augustus Kelley 1967 publication (pp. 19-23), which is a reprint of the 1797 edition of Francis Baring's Observations on the Establishment of the Bank of England and on the Paper Circulation of the Country. Baring, as well as importing the term, used it in a new, metaphorical way. In France it referred to the final court of appeal.

${ }^{28}$ Thornton's writing in Paper Credit continually interwove analysis with factual examples. In an early essay on the book, Francis Horner (writing in the Edinburgh Review) observed that this made Paper Credit hard to read and to understand and, accordingly, as well as praising the book's insights very highly, he summarized its analytical framework.
} 
And who was to "pour in" this gold? The Bank of England.

...If the Bank of England, in future seasons of alarm, should be disposed to extend its discounts in a greater degree than heretofore, then the threatened calamity may be averted.

(Thornton, 1802, p. 188)

This approach, however, was not incompatible with allowing some individual institutions to fail:

It is by no means intended to imply that it would become the Bank of England to relieve every distress which the rashness of country banks may bring upon them: the Bank by doing this, might encourage their improvidence... The relief should neither be so prompt and liberal as to exempt those who misconduct their business from all the natural consequences of their fault, nor so scanty and slow as deeply to involve the general interests.

(Thornton, 1802, p. 188)

The overriding concern should be with the system as a whole. The reason a "pouring into the circulation" (to use Thornton's phrase) would stop a panic and thus protect the system was described with great clarity by Bagehot in 1873:

What is wanted and what is necessary to stop a panic is to diffuse the impression that though money may be dear, still money is to be had. If people could really be convinced that they would have money...Most likely they would cease to run in such a herd-like way for money. (pp. 64-65)

In the British banking system in place by the mid to late nineteenth century - a system based on gold but with the central bank as the monopoly supplier of notes-the responsibility for diffusing "...the impression that... [m] oney is to be had" clearly rested with the central bank.

This brief synopsis summarizes nineteenthcentury theory on the subject of lender of last resort. Because the central bank was the sole permitted note issuer, it was the ultimate source of cash. If it did not, by acting as lender of last resort, supply that cash in a panic, the panic would continue, worsen, and bring about a widespread banking collapse along with a sharp monetary contraction.
What was nineteenth-century practice? A set of institutions (now gone) called discount houses that originated as bill brokers brought together those who wished to issue bills of exchange (an important means of trade finance) and investors who wished to purchase such bills. These brokers grew, built up their capital base, and ceased to be purely brokers, instead holding some bills on their own account. They then became "discount houses." In part because of a degree of animosity between the banks and the Bank of England (due to the latter's privileges), the banks preferred to place their surplus liquidity with the discount houses. These in turn had access to borrowing at the Bank of England by discounting bills there.

Within that setting, how did lender-of-lastresort practice develop? Sterling returned to its prewar gold parity in 1821. The first subsequent occasion for emergency assistance from the Bank was in 1825 after a substantial external drain of gold and resulting shortage of currency. A panic developed, and there were runs on banks. The type of bills the Bank would normally discount soon ran out and the panic continued. If a wave of bank failures was to be prevented, the banks would have had to borrow on the security of other types of assets. On December 14, the Bank of England suddenly deviated from its normal practice and made advances on government securities offered to it by the banks instead of limiting itself to discounting commercial bills. The panic was ended.

After several other episodes, the final step was taken in 1866, with the Overend, Gurney crisis. Overend, Gurney, and Co. originated with two eighteenth-century firms, the Gurney Bank (of Norwich) and the London firm of Richardson, Overend and Company. By the 1850s the combined firm was very large; its annual turnover of bills of exchange was equal in value to about half the national debt, and its balance sheet was ten times the size of the next-largest bank. It was floated during the stock market boom of 1865 . By early 1866 the boom had ended. Many firms were failing. Bank rate had been raised from 3 percent in July 1865 to 7 percent in January 1866. After February, Bank rate started to ease, but on May 11, Overend, Gurney was declared insolvent. 
As remarked in the June 1866 Bankers' Magazine, "a terror and anxiety took possession of men's minds for the remainder of that and the whole following day." The Bank of England briefly made matters worse by hesitating to lend even on government debt. The Bank Charter Act (which, among other things, restricted the note issue to the extent of the gold reserve plus a small fiduciary issue) was then suspended, and the panic gradually subsided. ${ }^{29}$

The 1878 failure of the City of Glasgow Bank was much less dramatic. It had started respectably, was managed fraudulently, and failed. It was feared that the Bank Charter Act would have to be suspended again (see Pressnell, 1968), but no major problems appeared: "There was no run, or any semblance of a run; there was no local discredit” (Gregory, 1929). Other Scottish banks took up all the notes of the bank; Gregory conjectures that they acted to preserve confidence in their own note issues.

Then in 1890 came the (first) "Baring crisis." Baring's was a large bank of great reputation; in 1877, when U.K. Treasury bills were introduced, Bagehot praised them as being "as good as Baring's.” Nevertheless, Baring's became involved in a financial crisis in Argentina. The Argentinean government had difficulty paying the interest on its debt in April 1890; then the Argentinean national bank suspended interest payments on its debt. This precipitated a run on the Argentinean banking system, and there was revolution on July 26. Baring's had lent heavily to Argentina. On November 8, it revealed the resulting difficulties to the Bank of England. The Bank (and the government) were horrified, fearing a run on London should Baring's default. A hurried inspection of Baring's suggested that the situation could be saved but that $£ 10$ million was needed to

\footnotetext{
${ }^{29}$ Suspension of the Act freed the note issue from the constraint of the Bank's gold reserves. This action has parallels in Italy later in the nineteenth century and again in East Asia in 1998. (For a brief discussion of that 1998 episode, see Wood, 1999.) There was also a parallel in the United States. The 1933 Banking Act (the GlassSteagall Act) broadened the collateral the Fed could hold against Federal Reserve notes. While the gold requirement was left unchanged at 40 percent, the Act added government bonds to the list of eligible paper that could make up the remaining 60 percent (see Benston, 1990).
}

finance current and imminent obligations. A consortium was organized, initially with $£ 17$ million of capital. By November 15 the news had leaked, and there was some switching of bills of exchange into cash. But there was no major panic and no run on London or on sterling. The impact on financial markets was small. Baring's was liquidated and refloated as a limited company with additional capital and new (but still family) management.

Why the great difference among the first, second, and third episodes of bank failures? The Bank of England had both learned to act as lender of last resort and made clear that it stood ready so to act. The Bank had erred in 1866 by lending “...hesitatingly, reluctantly, and with misgiving... In fact, to make large advances in this faltering way is to incur the evil of making them without obtaining the advantage" (Bagehot, 1802, p. 188).

So the lesson learned in Britain was that a banking crisis could be stopped by prompt lenderof-last-resort action. However, this does not mean that a central bank is obliged to provide funds to any institution facing liquidity problems. Today, banks have many sources of funding that were not available in the nineteenth century. They now have access to both unsecured interbank markets and secured short-term sale and repurchase (repo) markets. This means that there is no need for the central bank to provide direct liquidity support to any bank able to access either interbank or repo markets. Today the obligation as lender of last resort can be fulfilled by providing liquidity to the money markets as a whole.

\section{WHY DID THE TRIPARTITE AUTHORITIES PROVIDE SUPPORT AT ALL?}

What range of possibilities was considered by the Tripartite Authorities immediately before the loan facility was granted to Northern Rock? The options-Northern Rock's ability to refinance itself in the markets, finding a "safe haven," or Bank of England support-all differed from the traditional response (whether termed "lender of 
last resort" or "provision of liquidity to money markets") in that they involved something that must be called, in one sense or another, a "rescue."

The Authorities could have behaved as they had in the nineteenth century. They could have considered whether the troubled institution was of sufficient importance that its failure would have damaged the reputation of London, as they did in the Baring case in 1890, and if it failed that test it would have been allowed to sink or swim and liquidity would have been provided to the rest of the banking sector as needed to calm any subsequent panic.

The chosen option is well known-Northern Rock was not allowed to sink or swim. A determined attempt was made to keep the institution going and to find a rescuer for it. This approach certainly could not be justified by the size or reputation of Northern Rock. It was not a particularly large institution, and even its greatest admirer would not claim that it was a bank of international renown similar to that of Baring's in $1890 .{ }^{30}$ Why, then, did the Authorities act as they did? ${ }^{31}$

\section{A Possible Interpretation}

A range of factors probably influenced the decision. First, and most obvious, is that the problem was a shock-and one to previously untested regulatory and money market regimes. Also in play may have been some factors about which it is possible only to speculate at this time, although more data may become available in the future when the archives are opened (if written records of discussions were kept).

Gordon Brown had just become prime minister. Opinion polls suggested a subsequent sharp leap in the popularity of the ruling Labor government and there was much speculation that an

\footnotetext{
${ }^{30}$ In an article in The Times of January 22, 2008, Anatole Kaletsky made a similar contrast, presenting the sensible choices as either administration or nationalization, and condemning the chosen outcome as a device designed only to save the government's reputation, and one that would be costly to the taxpayer.

${ }^{31}$ On Monday, February 18, 2008, the government announced the latest development in the Northern Rock story. The bank was to be nationalized. It was in public ownership by Friday, February 22. The details of events leading up to this point are sparse and so are relegated to appendix 3 of the House of Commons report (HC 56-II, 2008b)
}

election would be called. Closing a bank (or nationalizing it) would probably have done little good for the government's prospects of victory. A second consideration is that such action might not have reflected well, at least in the popular press, on the "Tripartite Arrangements" for financial stability, and these arrangements had been put in place when Gordon Brown was Chancellor of the Exchequer. Third, Northern Rock was headquartered in an area of strong Labor party support (Newcastle on Tyne) and where unemployment was above the national average. The political background was not favorable for the "sink or swim" option.

There are, however, also undeniably good economic reasons why the traditional course of refusing support to an individual institution and leaving it to sink or swim was not followed. These reasons are further explored before showing how these impediments can be removed, thus allowing a return to the traditional approach in any future bank failure, and thereby diminishing the problem identified by Thornton and now referred to as "moral hazard":

\section{It is by no means intended to imply that it would become the Bank of England to relieve every distress which the rashness of country banks may bring upon them: the Bank by doing this, might encourage their improvidence.}

The first reason entails a technical aspect of the Bank's money market operations and then, more fundamentally, the nature of interbank linkages and retail bank depositors in the twenty-first century.

\section{Borrowing via the Standing Facility}

As described previously, the current system of money market operations used by the Bank of England allows commercial banks to choose their own level of cash reserves according to their expected need in the month ahead. If their forecast is wrong, they can earn interest on the surplus or borrow more through the standing facility. The problem arises with the latter. Borrowing moreat the "penalty" rate above the basic rate-is seen as revealing a mistake by the borrowing bank. There was, therefore, no way for the Bank of 
England to supply additional liquidity to Northern Rock through the standing facility, even if offered good and normally acceptable collateral, without giving the impression that Northern Rock had in some way blundered, thereby further eroding its ability to raise funding from the markets.

Under the money market system in use when the classic lender-of-last-resort system was developed, the discount houses were continually transacting with the Bank, frequently borrowing more than once per day. Hence, such borrowing was not considered abnormal and did nothing to cause alarm. In contrast, the new money market operating procedure, while perfectly capable of getting cash to banks at times of stress, did so in a way that highlighted the stress.

This fact suggests that it would be sensible to adopt arrangements where access to the standing facility at the 1 percent penalty rate is offered anonymously, since this would make it easier for banks individually and collectively to bridge an unexpected shortfall in liquidity. ${ }^{32}$ In the future, such an arrangement could help other institutions facing liquidity problems, but it would have been insufficient to prevent Northern Rock from defaulting on short-term obligations. Why? Northern Rock had such a large funding shortfall that it would not have had nearly enough eligible collateral (such as government bonds) to use for this type of borrowing. (At the time of Northern Rock's problems, the Bank of England did not accept mortgages or other loan assets, or even securitized mortgages, as collateral for access to the standing borrowing facility.) So it is clear that anonymous access to the standing facility, while possibly helpful in general, would not have resolved the liquidity problems at Northern Rock.

It can be argued that the Bank of England could still have provided support to Northern Rock through the standing facility by widening the range of eligible collateral. This solution, however, is problematic because other assets held by banks, such as retail or corporate loans, are illiquid and therefore very hard to value. Even when bank loans are made more liquid, through asset-

\footnotetext{
${ }^{32}$ Whether anonymity can be preserved when a large operation is ongoing is not as clear-the operation would almost certainly be noticed.
}

backed securitization, the tranches issued by the securitization vehicle are still not actively traded and are therefore very difficult to value. Thus, widening the range of eligible collateral would require very large "haircuts" (the margins by which the estimated value of the collateral must exceed the amount borrowed), which in turn would have further weakened Northern Rock's balance sheet. Northern Rock would have obtained liquidity but at the price of running out of capital.

Indeed, even with anonymity and widening of eligible collateral the standing borrowing facility would never be appropriate for the provision of funding on the scale required by Northern Rock: Its borrowing from the Bank of England eventually amounted to more than one-quarter of its total assets. A facility on such a scale far exceeds the normal needs of liquidity management and would necessitate careful assessment of the viability of the borrowing bank to ensure that it has sufficient financial resources for continued business viability and that it is not just borrowing to delay inevitable collapse. However it is arranged, the standing facility must be limited in magnitude.

\section{Interbank Linkages}

The nature and extent of interbank linkages create a problem with the sink-or-swim option. If a bank were to "sink" and go into liquidation, then its transactions, its assets, and its liabilities would be frozen. A court-appointed liquidator would try, by avoiding a "fire sale," to dispose of the assets at the best possible price, quite possibly taking some time to do so to minimize the loss for creditors. This process would cause immense problems for a modern banking system because it could leave many transactions uncompleted for months or even years. In an insolvency, repo borrowing (financing through an initial sale of a security and its later repurchase at a slightly higher price) is closed out, in a manner similar to overthe-counter derivative transactions, but unsecured borrowing, such as Northern Rock relied on because it lacked eligible collateral for repo financing, must be left to be finally resolved through the insolvency procedure. 


\section{Retail Depositors}

When "sink or swim" was the course of action, retail depositors differed in two ways from their modern-day counterparts. They were (relative to the population as a whole) more prosperous, and they did not rely to the same extent on bank transactions for day-to-day living-banking services were not as crucial to functioning in nineteenthcentury society as they are now. In Britain today the politicians, who make the ultimate decision over bank closure, could not tolerate bank customers, especially poor ones, losing both money and access to banking services. Indeed, aside from any questions of protecting savings, loss of access to banking services would impede economic efficiency in many ways-for example, forcing reliance on cash and unwarrantedly destroying credit ratings. Britain does have a deposit insurance scheme supposedly intended to deal with these things, but, as argued below, it is significantly defective.

\section{WHAT CAN BE DONE TO SOLVE BANKING CRISES?}

We propose three aspects of the system for dealing with banking problems: (i) the deposit insurance fund, (ii) bank support, and (iii) prompt closure and payout.

\section{Deposit Insurance}

Deposit insurance is needed because it is impossible to avoid a commitment to protect depositors. This commitment cannot be avoided, for both political and economic reasons. The public expects that its money will be safe with any bank that has a banking license. Thus, in the event of a bank failure, it is politically damaging for the government of the day to allow small depositors to suffer losses. This is not quite inevitable; small depositors have on occasion lost money. ${ }^{33}$ But it is difficult to avoid.

${ }^{33}$ Consider, for example, depositors in the Bank of Credit and Commerce International (BCCI). Depositors there had to rely on the deposit insurance fund. That case, however, was perhaps special since BCCI was closed because it was run fraudulently.
How large must a bank be in order to be politically "too big to fail"? One lesson of the Northern Rock situation is that the political necessity of supporting depositors seems to apply to much smaller banks today than it did in the past. A few years ago it was possible for covert financial support to be offered to a bank (in practice, this was then done indirectly, by persuading other banks to continue offering credit), and reports of concerned depositors queuing outside bank branches were not widely disseminated. ${ }^{34}$ Thus, the provision of support to bridge a wholesale funding gap might have been enough on its own to prevent a liquidity crisis. Nowadays, in contrast, even a relatively small bank requires a clear commitment to protect depositors to maintain the stability of the deposit base.

There are also good economic reasons for protecting depositors in both large and small banks. In the case of large banks, this is necessary to protect against the economic consequences of a loss of a significant share of household wealth. As we discuss further below, it is also clear that this support cannot be simply in the form of a cash payout; large banks that are "too big to fail" must be maintained as going concerns in order not to lead to loss of essential lending and payment functions. ${ }^{35}$ This obligation to support large banks in turn means that it is beneficial to protect depositors in smaller banks so that the smaller banks can compete effectively with the large banks that are perceived as "too big to fail." The difference is that a small bank may be allowed to "fail," provided depositors are promptly and fully compensated and arrangements, such as those described below, are made to ensure that these depositors continue to have access to banking services.

Deposit insurance cannot be avoided. Further, one of its benefits is that it is an explicit scheme because it can clearly state exactly who is protected and to what extent. This clarification then reduces the political pressure to provide a general

\footnotetext{
${ }^{34}$ Such depositor queues did take place at the time of the secondary banking crisis in the early 1970s but were not widely reported. This may be because the media of the day were more compliant.

${ }^{35}$ We emphasize that this does not mean that either management or shareholders are protected. It means simply that the operations of the bank are continued.
} 
bailout of uninsured depositors, other creditors, and perhaps even of shareholders.

How should this scheme operate in practice? The protection should be 100 percent up to an appropriate limit; $£ 35,000$ per depositor per institution-the limit set in the government guarantee arrangements for U.K. bank depositors following the crisis at Northern Rock-is surely sufficiently large. This guarantee would be large enough to fully protect a little over 90 percent of depositors.

Premia should be paid by banks on a regular basis, in proportion to the amount of their insured deposit liabilities. Premia might have an element of risk sensitivity (e.g., according to the leverage of the bank). These premia should then be paid into the deposit insurance fund so that it has financial resources available to deal with a bank failure immediately. This requires maintaining the fund at an appropriate percentage level of total insured deposits ( 5 percent of total deposits seems appropriate, but it is worth considering the exact target level for the fund in light of the experience of other countries). In the event of a benign period, with no calls on the fund's resources, then the fund will become full and premia can be reduced to the level needed to maintain the ratio of fund assets to insured deposits. The fund itself should be invested in very safe assets such as government securities.

The deposit insurance fund must be further supported through a guaranteed first line of credit from the central government so that it can deal with a bank failure larger than the amount in the fund. In the event of such a call in which the fund is forced to use this line of credit, insured banks will then be required, after the event, to pay relatively high deposit insurance premia, and if necessary a special levy, to restore the fund within a reasonable time frame.

The deposit insurance fund requires the further explicit financial backing of the government in the form of an open-ended second line of credit—with the difference between the first and second lines of credit that there is no obligation on other insured institutions to repay this second line. Instead, once the crisis is resolved, the government will absorb this liability on its own books. We outline the reasons for this second line of credit after the discussion of our bank closure proposals.

These funding arrangements, by building up assets in the fund and with lines of credit from the central government, avoid the principal problem of pure private sector deposit insurance: imposing relatively large contributions on banks when the economy is weak and banks' capital is under pressure. The remaining problem is determining how rapidly to build the fund to its desired level, both when it is first established and after any major call on the fund's resources. Some flexibility in the speed of repletion may be in order, depending on banks' abilities to provide the necessary funding.

\section{Bank Support}

We now turn to the second element of reform: clear but strictly limited procedures for the provision of financial support. As our previous discussion makes clear, offering bank support is not a lender-of-last-resort operation; it does not involve providing liquidity to the market as a whole to prevent a run for cash. However, it is also clear that the option of letting any bank in liquidity difficulties fail may create both inefficiency and systemic problems.

Inefficiency arises because the refusal to provide short-term liquidity to an institution that cannot obtain credit from the private sector threatens solvency. If the problem cannot be quickly resolved by private sector arrangements (e.g., a takeover or a recapitalization), then the resulting reorganization of the bank can lead to substantial loss of value. Systemic problems arise because the failure to provide short-term support can affect other financial institutions; such effects could be in the form of loss of confidence among uninsured depositors or increases in spreads in interbank markets.

Support to a troubled bank must be provided on strict terms. First, it must be provided against collateral—enough collateral and of sufficient quality - so that the risk of credit loss arising from the support operation is negligible. Unlike the situation with the standing facility, no strict rules are needed for collateral eligibility; this collateral could include loans or nonstandard securities, 
but the valuation must be conservative. Second, it must be provided at a penalty cost above market rates for collateralized borrowing so that the provision of government liquidity is not a liquidity subsidy. Finally, the support must be strictly limited in duration, with a requirement for transfer of control from shareholders to the financial authorities after a defined period, which we believe should be about three months.

\section{Prompt Closure and Payout}

Our third provision in bank crisis resolution is the need for special procedures for intervention in a financial institution to resolve its financial distress and make a rapid payout to depositors. At present, this is not possible in the United Kingdom because closure follows standard U.K. corporate insolvency law: A creditor applies to put a business into administration, and the provider of liquidity support and the deposit insurance fund then have no preference over other creditors. A new legal framework is required.

This proposed framework requires that intervention in a bank, in which shareholders lose both ownership and control rights, must take place in either of the two following circumstances:

- when the maximum period of 3 months of support operation has passed or

- when net worth declines below some minimum level(s), short of balance-sheet insolvency; this might correspond to the usual Basel requirement on risk-weighted capitalization with intervention at the tier 1 level of 4 percent; but a simpler additional requirement might be to intervene based on unweighted leverage (equity as a proportion of total assets).

Different mechanisms that could be used for such intervention include the following:

- The bank could operate as a going concern, but with cash flow subsidy from the deposit insurance fund, with a view to preparing it for a private sector sale. Shareholders then could be reimbursed if the proceeds of this sale exceeded the amount needed to reimburse the fund.
- The bank could transfer deposits to another financial institution, together with cash from the deposit insurance fund. The bank assets could be reorganized or sold to pay out liability holders with the deposit insurance fund first in the queue and the shareholders last. ${ }^{36}$

- The bank could transfer deposits, together with performing assets, to a "bridge bank" (requiring an injection of funds from the deposit insurance fund) and prepare this bank for sale. The deposit insurance fund would then acquire a claim on remaining nonperforming assets, with shareholders receiving payment only if these eventually realize more than the transfer from the deposit insurance fund.

If an effective prompt closure scheme is already in place, why do we believe there will be any need at all for bank support? We think this is still required because prompt closure (of the kind mandated, for example, by the U.S. Federal Deposit Insurance Corporation Improvement Act) is always based on accounting measures such as net worth. Where substantial off-balance-sheet problems exist (as was the case for Northern Rock), the first sign of difficulties is likely to be a withdrawal of wholesale funding, but it is not then necessarily appropriate for the authorities to move the bank directly into the closure regime.

The possibility of offering temporary bank support against collateral should be an alternative option to immediate closure. The authorities should have the right-but not the obligationto provide this type of support (and they will not be likely to do so if the sums involved are so large as to suggest inevitable closure).

We do not consider in detail the arguments over whether this short-term support is to be publicly disclosed, but it is reasonable to maintain that disclosure should be on the same terms

\footnotetext{
${ }^{36}$ This order of priority follows U.S. practice. The virtue of that approach is that it has been tested and has worked. But if the deposit insurance fund were to come second-last in priority, preceding only shareholders, then it would have a powerful incentive to maximize the value realized for the business, and that is desirable from the point of view of achieving efficient use of the business's resources.
} 
as other bank wholesale borrowing (i.e., the bank must disclose it has borrowed against collateral so that other debtholders are aware) but need not say that it is the government that has via the central bank provided this support. Of course, for large banks it would not be possible to keep the support quiet.

The merits and demerits of the various approaches to bank closure are not compared in this paper. We do, however, note that any resolution other than maintaining the bank as a going concern involves tricky technical problems of account transfer. This is no longer the nineteenth century, and bank rescue no longer means just a cash payout to depositors. Depositors need to be able to continue holding deposits and making and receiving payments. This means that salary and other payments will need to be rerouted and direct debits and other payment arrangements transferred. This, in turn, means that depositors need to have within a very short period (say 48 hours) either a clean transfer of all their banking arrangements to a new institution (either existing or de novo) or reorganization of the troubled institution (with all nonperforming assets removed) so that banking services then can be provided on an ongoing basis thereafter.

Transfer of accounts to a new institution is technically difficult. The various routing codes (sort codes in the United Kingdom) and bank account numbers must be updated. Payment arrangements must be transferred, and new payments cards may have to be issued. Even if the existing systems architecture of the bank is transferred to a new bridge bank (so that from the depositors' perspective they are dealing with the same institution as before), systems transfer problems arise with the nonperforming assets transferred out of the bank. Loan accounts still need to be monitored and repayments credited to these accounts. Staff will need to manage accounts in default. Given these requirements, it is clear that detailed consultation with the industry will be needed, perhaps through the U.K. Payments Council, to develop practical procedures.

\section{CONCLUSION}

This paper has shown how the highly unusual business model pursued by Northern Rock made it especially vulnerable to liquidity problems after repricing of credit risk in global markets during the summer of 2007. Britain was lucky in the resolution of the Northern Rock affair. Confusion in how official actions were announced undoubtedly created anxiety, but for all practical purposes the run was confined to Northern Rock. This fortunate result may have been a beneficial spillover from the government deposit guarantee that Northern Rock received, or perhaps it was due to a well-entrenched belief that British banks were safe. ${ }^{37}$ Such luck cannot be relied on for the future.

We propose the following actions to make the British banking system robust once more. ${ }^{38}$ First, there should be arrangements for prompt and orderly closure of a troubled bank-before it would otherwise be forced to close by either insolvency or illiquidity. Second, deposit insurance should be reformed so that whatever sum is guaranteed is completely guaranteed and can be accessed without any significant delay-by this, we mean essentially one business day. This requirement, of course, implies a cap on the guarantee at a fairly modest level. We have seen no arguments for raising the cap above the present level of $£ 35,000$; that amount would cover more than 90 percent of retail sterling bank deposits. Third, arrangements are needed so that customers retain access to all core banking services, either through speedy transfer of all accounts or the continued operation in some guise of the troubled bank.

With these reforms in place, Britain should be able to return once more to its classic, welltested method of dealing with banking problems as first fully set out by Henry Thornton in 1802 . These measures would preserve financial stability without encouraging bad, imprudent, or even

\footnotetext{
${ }^{37}$ The guarantee given to Northern Rock depositors was briefly extended to depositors at other banks, but there were few signs of other runs starting even before that was done.

${ }^{38}$ These proposals do not concern themselves with reform of regulatory and supervisory structures. Proposal for such changes, wholly compatible with the proposals in this paper and fully supported by its authors, are in the report of the Treasury Select Committee.
} 
reckless banking-and there is quite enough of that already around without encouraging it further. And so we hope that these or similar proposals are implemented soon.

\section{REFERENCES}

Bagehot, Walter. Lombard Street: A Description of the Money Market. London: Henry King, 1873.

Bankers’ Magazine. June 1866, pp. 45-46.

Bank of England. Inflation Report: May 2007. London: House of Commons Papers, Stationery Office; www.bankofengland.co.uk/publications/ inflationreport/ir07may.pdf.

Bank of England News Release. "Liquidity Support Facility for Northern Rock plc,” September 14, 2007; www.hm-treasury.gov.uk/media/6/9/pn94 07.pdf.

Baring, Francis. Observations on the Establishment of the Bank of England and the Paper Circulation of the Country (1797); as reprinted from the facsimile reprint. New York: Augustus Kelley, 1967, pp. 19-23.

Benston, George J. The Separation of Commercial and Investment Banking: The Glass-Steagall Act Revisited and Reconsidered. Oxford: Oxford University Press, 1990.

Gregory, T.E. Select Statistics, Documents and Reports Relating to British Banking 1832-1928. Oxford: Oxford University Press, 1929.

House of Commons Treasury Committee. The run on the Rock. Fifth report of Session 2007-08, Volume I. Report, together with formal minutes (HC 56-I).
London: The Stationery Office Limited, January 24, 2008a; www.publications.parliament.uk/pa/ cm200708/cmselect/cmtreasy/56/56i.pdf.

House of Commons Treasury Committee. The run on the Rock. Fifth report of Session 2007-08, Volume II. Oral and written evidence (HC 56-II). London: The Stationery Office Limited, January 24, 2008b; www.parliament.the-stationery-office.co.uk/pa/ cm200708/cmselect/cmtreasy/56/56ii.pdf.

Kaletsky, Anatole. “Gordon Brown’s Black Wednesday: The Northern Rock disaster has torn away any remaining credibility the Prime Minister had." The Times, January 22, 2008, p. 21; www.timesonline.co.uk/tol/comment/columnists/ anatole kaletsky/article3227927.ece.

Pressnel, Leslie. "Gold Flows, Banking Reserves and the Baring Crisis of 1890," in C.R. Whittlesey and J.S.G. Wilson, eds., Essays in Money and Banking in Honour of RS Sayers. Oxford: Clarendon Press, 1968.

Reid, Margaret. The Secondary Banking Crisis. London: Hindsight Books Ltd., 1976 (reprinted 2003).

Thornton, Henry. An Enquiry into the Nature and Effects of the Paper Credit of Great Britain. Facsimile, 1802. Reprinted (with introduction by Friedrich A. Hayek). Fairfield, NJ: Augustus Kelley, 1978.

Wood, Geoffrey E. "The Lender of Last Resort Reconsidered." Journal of Financial Services Research, December 2000, 18(2/3), pp. 203-27. 